TEME, г. XLIII, бр. 4, октобар - децембар 2019, стр. 1095-1108

\begin{tabular}{lr}
\hline Оригинални научни рад & https://doi.org/10.22190/TEME191017065M \\
Примљено: 17. 10. 2019. & UDK 342.726-056.26/.29(497.1)
\end{tabular}

Ревидирана верзија: 21. 10. 2019.

Одобрено за штампу: 1. 12. 2019.

\title{
AWARENESS OF PERSONS WITH DISABILITIES OF CRIMINAL JUSTICE PROTECTION AGAINST DISCRIMINATION IN THE FORMER SFRY COUNTRIES
}

\author{
Filip Mirić \\ University of Niš, Faculty of Law, Niš, Serbia \\ filip@prafak.ni.ac.rs
}

\begin{abstract}
Discrimination against persons with disabilities is a widespread social phenomenon. In recent years, Serbia has successfully completed its normative framework by adopting a number of laws in the field of protection against discrimination (Act on Prevention of Discrimination against Persons with Disabilities, Act on Prohibition of Discrimination, Act on Professional Rehabilitation and Employment of Persons with Disabilities). Civil law protection and compensation for pecuniary and non-pecuniary damage are the most common forms of protection against discrimination. In addition to civil protection, the legal order of the Republic of Serbia also prescribes criminal law protection against discrimination. The aim of the paper is to investigate, by means of a specially designed questionnaire, the degree of awareness of persons with disabilities of the mechanisms of criminal law protection against discrimination. Being aware of one's rights and how to protect them is a prerequisite for successful implementation of legal solutions. The results of the research show that persons with disabilities in Serbia are insufficiently informed about the available mechanisms for criminal justice protection against discrimination. As a result, there is a very small number of completed criminal proceedings in this field, which is one of the reasons for the unfavorable social and legal position of this vulnerable social group in Serbia.
\end{abstract}

Key words: crime, persons with disabilities, discrimination, criminal legislation.

\section{ИНФОРМИСАНОСТ ОСОБА СА ИНВАЛИДИТЕТОМ О КРИВИЧНОПРАВНОЈ ЗАШТИТИ ОД ДИСКРИМИНАЦИЈЕ У ДРЖАВАМА БИВШЕ СФРЈ}

\section{Апстракт}

Дискриминација особа са инвалидитетом је веома распрострањен друштвени феномен. Последњих година Србија је, усвајањем низа закона из области заштите од дискриминације (Закон о спречавању дискриминације особа са инвалидитетом, Закон о забрани дискриминације, Закон о професионалној рехабилитацији и запошљавању особа са инвалидитетом), успешно заокружила свој нормативни оквир. Када је реч о заштити од дискриминације, обично се мисли на грађанскоправну заштиту и 
на накнаду материјалне и нематеријалне штете. Осим грађанскоправне заштите, правни поредак Републике Србије прописује и кривичноправну заштиту од дискриминације. Циљ рада је да се, коришћењем посебно дизајнираног упитника, истражи колико су саме особе са инвалидитетом упознате са механизмима кривичноправне заштите од дискриминације. Информисаност о правима и начину њихове заштите је предуслов успешне примене законских решења. Резултати спроведеног истраживања су показали су да особе са инвалидитетом у Србији нису у довољној мери информисани о начинима кривичноправне дискриминације. У овоме треба тражити и узрок веома малог броја окончаних кривичних поступака из ове области у Србији, што је један од разлога неповољног друштвеног и правног положаја ове групе људи.

Кључне речи: криминалитет, особе са инвалидитетом, дискриминација, кривично законодавство.

\section{INTRODUCTORY NOTES}

In order to enjoy the full scope of their rights, people should be adequately informed about the manner and conditions for their implementation. This is especially true for people with disabilities who have been on the sidelines of social developments for years. Unfortunately, discrimination is a negative social phenomenon that persons with disabilities in Serbia, and in the region, face almost daily to a greater or lesser extent. Much has been said and written about discrimination in recent years. Discrimination covers a wide range of topics (Petrušić et al., 2012, p. 28). With all this in mind, the aim of the research conducted for the purposes of this paper is to explore, through the use of a specially designed questionnaire, the degree of awareness of persons with disabilities of the mechanisms of criminal justiceprotection against discrimination. Today, discrimination against persons with disabilities is present in all countries of the former SFRY.

The first part of the paper provides a summary of the legal framework concerning criminal law protection against discrimination in the countries that emerged after the breakup of the SFRY. Then, the author analyzes and interprets the data collected in the empirical research. On the basis of the presented findings, the author draws conclusions and suggests further action to improve the situation in this area.

\section{COMPARATIVE OVERVIEW OF CRIMINAL LAW PROTECTION AGAINST DISCRIMINATION IN THE FORMER SFRY COUNTRIES}

Persons with disabilities enjoy protection against discrimination under the criminal legislation.In Serbia, the basic source of criminal law is the Criminal Code of the Republic of Serbia, ${ }^{1}$ but it should be noted

${ }^{1}$ Krivični zakonikRepublike Srbije (Criminal Code of Republic of Serbia), „Službeni glasnik Republike Srbije“ br.85/2005...94/2016. 
that the criminal law protection of persons with disabilities is incomplete and fragmentary. This was a subject of many theoretical and empirical researches and analysis especially in countries of former SFRY.

First of all, we should mention the criminal offense of violation of equality under Article 128 of the Criminal Code of the Republic of Serbia (hereinafter referred to as CC). The qualified form of the said criminal offenseexists if it is committed by an official in the discharge of duty, which is punishable by imprisonment of up to five years. The perpetrator of this criminal offense may be any person who is in a position to decide on the exercise of one's rights and interests (Jovašević, 2006, p. 480). Another important offence envisaged in Article 387 of the Serbian Criminal Code is the criminal offense of racial and other discrimination. The basic form of this criminal offense is committed by anyone who, on the grounds of differences in race, color, religion, nationality, ethnic origin or some other personal characteristic, violates the fundamental human rights and freedoms guaranteed by the universally accepted rules of international law and international treaties ratified by Serbia; the perpetrator of such a crime may be punished by a term of imprisonment ranging from six months to five years. Apart from this, there are other forms of the same criminal offense. The same punishment (imprisonment ranging from six months to five years) will be imposed on those who persecute organizations or individuals for their efforts to promote equality. Anyone whospreads ideas about the superiority of one race over another, or propagates racial hatred or incites racial discrimination, will be punished by imprisonment ranging from three months to three years. Anyone who disseminates or otherwise makes public texts, pictures or any other representation of ideas or theories that advocate or encourage hatred, discrimination or violence against any person or group of persons based on race, skin color, religious affiliation, nationality, ethnicity origin or other personal property, shall be punished by a sentence of imprisonment ranging from three months to three years. Whoever publicly threatens to commit a criminal offense punishable by imprisonment exceeding four years against a person or a group of persons belonging to a particular race, color, religion, nationality, ethnic origin or other personal property, shall be punished by imprisonment from three months to three years. The criminalization of equality violations from Article $128 \mathrm{CC}$ can be considereda positive development. Namely, the amendments to the Criminal Code (adopted in 2016) also mention disability as one of the grounds for the violation of equality, which is in compliance with Article 21 of the Constitution of the Republic of Serbia concerning the prohibition of discrimination. $^{2}$

\footnotetext{
${ }^{2}$ See: UstavRepublike Srbije (Constitution of Republic of Serbia), „Službeni glasnik Republike Srbije “ br. 98/2006, i Zakon o izmenama i dopunama Krivičnog zakonika
} 
Similar legal solutions exist in the criminal legislations of certain states of the former SFRY. For example, the Criminal Code of the Republic of Croatia (hereinafter: CC RC) prescribes the criminal offense of violation of equality, envisaging that "whoever, on the basis of race, ethnic affiliation, skin colour, gender, language, religion, political and other convictions, national or social origin, property, birth, education, social status, marital or family status, age, state of health, disability, genetic inheritance, gender identity, expression, sexual orientation or other characteristics, denies, limits or conditions another the right to acquire goods or receive services, the right to carry out an activity, the right to employment and promotion, or whoever on the basis of any such characteristic or affiliation gives another privileges or advantages, shall be punished by imprisonment not exceeding three years" (Article 125 of CC RC). ${ }^{3}$ Article 325 of the Criminal Code of the Republic of Croatia, which prescribes the criminal offense of public incitement to violence and hatred, is particularly important from the aspect of the protection of persons with disabilities.This offense envisages that any person who "through the press, radio, television, computer system or network, at a public gathering or in some other way publicly incites or makes available to the public leaflets, pictures or other material instigating violence or hatred directed against a group of persons or a member of such a group on account of their race, religion, national or ethnic origin, descent,colour, gender, sexual orientation, gender identity, disability or any other characteristics, shall be punished by imprisonment not exceeding three years" (Article 325 of CC RC). Moreover, in cases involving criminal offenses with elements of violence which are committed against a person with disabilities, criminal prosecution is undertaken ex officio. ${ }^{4}$

A similar legal solution on racial and other discrimination exists in the Criminal Code of Montenegro (hereinafter: CCMNE). Thus, Article 443 (3) of the CCMNE stipulates that "anyone who spreads ideas about the superiority of one race over another or propagates hatred or intolerance based on race, sex, sexual orientation, gender identity or other personal characteristics or incites racial or other discrimination, shall be punished by imprisonment from three months to five years. ${ }^{5}$ From the aspect of protecting people with disabilities, this solution can be assessed as positive.

The Criminal Code of the Republic of Slovenia prescribes the criminal offense of violation of equality but does not stipulate disability

Republike Srbije (Act on Amendments to the Criminal Code of the Republic of Serbia), „Službeni glasnik Republike Srbije“ br. 96/2016.

${ }^{3}$ Kazneni zakonik Republike Hrvatske (Criminal Code of Republic of Croatia), „Narodne novine“, br.125/2011,... 118/2018.

${ }^{4}$ See: Art.138. and Art. 139. Criminal Code of the Republic of Croatia.

${ }^{5}$ Krivični zakonik Crne Gore (Criminal Code of the Republic of Montenegro), „Službeni list RCG“ i Službeni list CG“,, 70/2003...49/2018. 
as a special discrimination ground for violation of equality. ${ }^{6}$ Similarly, the Criminal Code of the Republic of Macedonia (CCRM) does not stipulate disability as grounds for discrimination either in the criminal offense of violation of the equality (Article 137 of the CCRM) or in the criminal offense of racial or other discrimination (Article $417 \mathrm{CCRM}$ ). ${ }^{7}$ Such solutions in the criminal legislation of Northern Macedonia certainly do not contribute to the protection of persons with disabilities from discrimination as a socially dangerous behavior.

The main problem in the criminal law system in Bosniaand Herzegovina is legal particularism. There are four Criminal Acts/Codes. As for the criminal legislation in the Federation of Bosnia and Herzegovina, in addition to the Criminal Act of the Federation of Bosnia and Herzegovina, it should be noted that each entity hasitsown legislative act: the Criminal Codeof Bosnia and Herzegovina, the Criminal Code of Republika Srpska, and the Criminal Act of Brčko District.Article 145 of the Criminal Code of Bosnia and Herzegovina ${ }^{8}$ contains the criminal offense of infringement of the equality of individuals and citizens, but it does not refer to disability as separate grounds for equality violation, not even through the generic term "other personal property" which would at least provide indirect criminal law protection against discrimination to persons with disabilities. Article 139 of the Criminal Code of the Republic of Srpska prescribes the criminal offense of violation of equality butdisabilityis not envisagedas grounds for equality violation. ${ }^{9}$ Article 174 of the Criminal Act of Brčko District does not envisage disability as grounds fordiscrimination for equality violation either. ${ }^{10}$ Similarly, Article 177 of the Criminal Act of the Federation of Bosnia and Herzegovina does not envisage disability as a discrimination ground. Thus, none of these legislative acts provide appropriate criminal law protection to persons with disabilities. ${ }^{11}$

On the basis of this brief overview of the criminal law legislation of the states formed after the disintegration of the former SFRY, it can be concluded that none of these countries has properly recognized the significance of the criminal protection of persons with disabilities. Some

${ }^{6}$ Kazenenski zakonik Republike Slovenije (Criminal Code of the Republic of Slovenia), „Uradni list Slovenije“, 55/2008...27/2017.

${ }^{7}$ Krivičen zakonik na Republika Makedonija (Criminal Code of the Republic of Macedonia), ,Služben vesnik na RM“, 80/99...132/2014.

${ }^{8}$ Krivični zakon Bosne i Hercegovine (Criminal Codeof Bosnia and Herzegovina), „Službeni glasnik Bosne i Hercegovine“, 3/2003...35/2018.

${ }^{9}$ Krivični zakonik Republike Srpske (Criminal Code of Republic of Srpska), „Službeni glasnik Republike Srpske“, 64/2017, 104/2018.

${ }_{10}^{10}$ Krivični zakon Brčko Distrikta Bosne i Hercegovine (Criminal Act of Brčko District of Bosnia and Herzegovina),,,Slubeni glasnik BD B i H“,33/2013 ...50/2018.

${ }^{11}$ Krivični zakonFederacije Bosne i Hercegovine (Criminal Act of Federation of Bosnia and Herzegovina), ,Službene novine FBiH“, 36/2003...75/2017. 
of these states have separate laws (lex specialis) on the prohibition of discrimination against persons with disabilities, which include penal provisions. ${ }^{12}$ However, we consider that misdemeanor law protection is insufficient to sanction all those unlawful activities that put persons with disabilities into a substantially unequal position as compared to other citizens. The amendments to the criminal legislation of the Republic of Serbia provide grounds to believe that the perpetrators of the criminal offense of equality violation will be adequately sanctioned in the future. ${ }^{13}$

The findings of this research show that there is a lack of judicial practice in the area of legal protection of people with disabilities in criminal law in the former SFRY countries. As an example, we will present the case of Dalibor Đorđević -a Croatian citizen with a physical impairment and a learning disability, who was subjected to on-going abuse and a violent physical assaultover a period of four years. The Police intervened when called upon, but they did not take concrete action. In 2012, the European Court of Human Rights stated in a landmark ruling that the state had failed in its obligation to protect him from continued abuse. This case re-emphasizes the role that the authorities must play to effectively counter hate crimes against people with disabilities. ${ }^{14}$ This was an important victory for Đorđević and the people with disabilities who face intolerance on a daily basis, and a guiding principle tohow people with disabilities should react in case of discrimination and abuse.

\section{EXAMINATION OF THE LEVEL OF AWARENESS OF PERSONS WITH DISABILITIES ABOUT CRIMINAL LAW PROTECTION AGAINST DISCRIMINATION}

\subsection{Introduction and Methodology}

Considering that successful protection against discrimination presupposes that citizens are well informed about the protection mechanisms, it is necessary to examine to what extent persons with disabilities are informed about the possibilities of criminal law protection against discrimination as a negative social phenomenon. For the purposes of this

\footnotetext{
${ }^{12}$ See: Zakon o sprečavanju diskriminacije osoba sa invaliditetom (Act on Prevention of Discrimination against Persons with Disabilities,,Službeni glasnik RS“, 33/2006. This legislative act is a lex specialis; it is a kind of curiosity in the anti-discrimination legislation of the Republic of Serbia that this Act was adopted before the AntiDiscrimination Act.

${ }^{13}$ For more about the earlier situation of criminal legislation in Serbia see: Mirić, 2017, p. 217-218. The overview of the criminal legislation in the former SFRY counties was cited after Mirić, 2017, p. 217-218.

${ }^{14}$ Hate Crime against People with Disabilities, https://www.osce.org/odihr/hate-crimeagainst-people-with-disabilities?download=true;accessed on 17 November 2019.
} 
paper, the survey on criminal protection of persons with disabilities included the users of the social network Facebook. The main objective of the research was to determine to which extent Facebook users, persons with disabilities, recognize criminal legislation in Serbia as an effective tool in the fight against discrimination involving persons with disabilities. The research aimed to test two hypotheses. The first hypothesis was that users of social networks with disabilities were insufficiently aware of the criminal law protection against discrimination; the second hypothesis was that a vast majority of respondents consider that criminal and civil court proceedings are equally important for combating discrimination against persons with disabilities. The survey was conducted using a questionnaire comprised of eight questions. Each question included a list of structured multiple answers, and the respondent was prompted to answer by choosing one of the provided options. The research instrument was designed to facilitate the statistical processing of the obtained results. The questionnaire was made publicly available on Facebook, in several online groups that gather people with disabilities. It should be noted that it was impossible to predict the research sample in advance. The survey was primarily aimed to examine the views of Facebook users, persons with disabilities. The participation in the survey was voluntary and anonymous.

The questionnaire was available to the general public from $17^{\text {th }}$ Aprilto $17^{\text {th }}$ July 2018, during which time a total of 34 Facebook users (respondents) participated in the survey. In the course of the survey, it was noted that there was no greater interest among persons with disabilities to participate in such projects. This situation imposes the need to take action in the future to instigate campaigns aimed at raising awareness of the importance of protecting persons with disabilities through the criminal justice system. The data obtained were processed in the GNU PSPP Statistical Analysis Software.

\subsection{Results and Discussion}

This part of the paper will present the results of the research through a summary of the respondents' answers to each of the questions in the questionnaire.

Table 1. Respondent's country of residence

\begin{tabular}{lcc}
\hline Country & Frequency & Percent \\
\hline Serbia & 29 & 85.29 \\
Bosnia and Herzegovina & 2 & 5.88 \\
Slovenia & 2 & 5.88 \\
Croatia & 1 & 2.94 \\
\hline Total & 34 & 100.00 \\
\hline
\end{tabular}


The questionnaire was completed by a total of 34 respondents. According to the data contained in Table 1, as many as $29(85.29 \%)$ of respondents live in Serbia, 2 in Bosnia and Herzegovina and 2 in Slovenia $(5.88 \%$ each), and only $1(2.94 \%)$ in Croatia. On the basis of these data, it can be concluded that the data obtained in this survey is mostly related to Serbia since a negligible number of respondents came from other countries. Such a responsemay be attributed to the fact thatit was impossible to anticipate and control the structure of Facebook social network users who wanted to participate in the survey.

Table 2. Respondents' structure by age

\begin{tabular}{lcc}
\hline Age group & Frequency & Percent \\
\hline $18-35$ & 12 & 35.29 \\
$36-49$ & 15 & 44.12 \\
$50-60$ & 4 & 11.76 \\
$60-70$ & 2 & 5.88 \\
$70+$ & 1 & 2.94 \\
\hline Total & 34 & 100.00 \\
\hline
\end{tabular}

The data contained in Table 2 show that the largest number of respondents fall into the 36-49 year age group (44.12\%), followed by the 18-35 year age group (35.29\%), while the lowestnumber of respondents (2 respondents only) belong to the 70+age group. Such results are expected, bearing in mind that it is known from experience that older persons are least likely to use social networks.

Table 3. Respondents' level of education

\begin{tabular}{lcc}
\hline Education & Frequency & Percent \\
\hline Elementary school & 3 & 8.82 \\
Secondary/High school & 13 & 38.24 \\
Higher education vocational studies (2-3 years) & 5 & 14.71 \\
Undergraduate academic studies (4 years) & 6 & 17.65 \\
Master/Magister studies (1-2 years) & 4 & 11.76 \\
Doctoral studies & 3 & 8.82 \\
\hline Total & 34 & 100.00 \\
\hline
\end{tabular}

As for the level of education, the majority of respondents completed high school (13), followed by the respondents who completed higher education/vocational studies (5), university undergraduate studies (6), master/magister degree studies (4), doctoral studies (3) and elementary school (3). The survey confirmed the well-known hypothesis that persons who complete secondary/high school education are prevalent among persons with disabilities. 
Table 4. Type of disability

\begin{tabular}{lcr}
\hline Disability & Frequency & Percent \\
\hline Intellectual disability & 1 & 2.94 \\
Physical disability & 22 & 64.71 \\
Sensory disability & 1 & 2.94 \\
Mixed (multiple) disability & 4 & 11.76 \\
I don't want to answer & 6 & 17.65 \\
\hline Total & 34 & 100.00 \\
\hline
\end{tabular}

Considering the type of disability, the majority of respondents had some form of physical disability (22), mixed/multiple disability (4), sensory disability (1), intellectual disability (1), while 6 respondents $(17.65 \%)$ did not want to state their type of disability. This shows that the number of respondents who do not want to discuss issues related to their disability is negligible. If the findings of future research show that there is such a tendency in the population of persons with disabilities, it would be much more difficult to create affirmative measures for this category of people.

Table 5. Social status of persons with disabilities

\begin{tabular}{lcc}
\hline Social status & Frequency & Percent \\
\hline Bad & 20 & 58.82 \\
Very bad & 13 & 38.24 \\
Good & 0 & 0.00 \\
Very good & 0 & 0.00 \\
I have no opinion & 1 & 2.94 \\
\hline Total & 34 & 100.00 \\
\hline
\end{tabular}

The data contained in Table 5 indicate that over half of the respondents $(58.82 \%)$ believe that the social status of persons with disabilities in the country where they live is bad, $38.24 \%$ think that it is very bad, and 1 respondent (2.94\%) has no opinion on this issue. Interestingly, none of the respondents rated the social status of persons with disabilities as good or very good. These findings clearly illustrate how people with disabilities perceive their social status.

Table 6. Effectiveness of court proceedings in combating discrimination against persons with disabilities.

\begin{tabular}{lcr}
\hline Court proceedings & Frequency & Percent \\
\hline Criminal Procedure & 5 & 14.71 \\
Civil Procedure & 3 & 8.82 \\
Both & 20 & 58.82 \\
I have noopinion & 6 & 17.65 \\
\hline Total & 34 & 100.00 \\
\hline
\end{tabular}


Table 6 shows the respondents' opinions on the question: Which court procedure do you consider to be more effective in combating discrimination against persons with disabilities?The collected data indicate that 5 respondents $(14,71 \%)$ considered criminal procedure to be more effective than civil procedure $(8,82 \%$ of respondents), 6 respondents $(17,65 \%)$ did not have a position on this issue while 20 respondents $(58.82 \%)$ considered that both criminal and civil procedure were equally effective. This confirms the hypothesis that most respondents believe that criminal and civil court proceedings are equally important in combating discrimination against persons with disabilities. It is encouraging that the majority of respondents believe in the unity of the legal system in combating discrimination.

Table 7. Discrimination as a crime

\begin{tabular}{lcc}
\hline Discrimination as a crime & Frequency & Percent \\
\hline Yes & 21 & 61.76 \\
No & 3 & 8.82 \\
I don't know & 10 & 29.41 \\
\hline Total & 34 & 100.00 \\
\hline
\end{tabular}

Table 7 shows very significant findings on the nature of discrimination. As many as $61.76 \%$ of respondents believe that discrimination is a crime, and only $8.82 \%$ of respondents believe that it is not a crime. Interestingly, almost a third of respondents (29.41\%) do not know the answer to this question.

Table 8. Awareness of persons with disabilities about criminal justicemechanisms for protection against discrimination

\begin{tabular}{lcc}
\hline Awareness of persons with disabilities & Frequency & Percent \\
\hline Yes & 6 & 17.65 \\
No & 24 & 70.59 \\
I don't have an opinion & 2 & 5.88 \\
Without answer & 2 & 5.88 \\
\hline Total & 34 & 100.00 \\
\hline
\end{tabular}

The results presented in Table 8 confirm the first hypothesis. Even though they largely recognize discrimination as a crime, persons with disabilities areneitheraware of ,norproperly informed about the criminal justice mechanisms for protection against discrimination. As many as $70.59 \%$ of respondents do not have enough information on this matter.This large percentage of under-informed respondents imposes the need to create active policies to raise awareness of persons with disabilities about the available mechanisms of legal protection against discrimination. Unfortunately, the findings of this research show that there is insufficient number of studies and scientific articles about the level of awareness of 
persons with disabilities about relevant criminal law protection against discrimination. One of the limitations of this research is that it is based on a small sample of respondents. However, the results presented in this paper may serve as a solid ground for futuremore extensive examination of this matter.

\section{CONCLUSION}

According to the brief overview of the criminal legislation of the former SFRY countries, it can be concluded that, in most of them, disability is not recognized either as a specific basis of discrimination or as a substantive element of thecriminal offense of violation of equality. This state of affairs in the legislation creates a legal gap, which can only be filled by subsuming disability under the generic term "other personal property". Thisultimately causes a series of problems when proving disability-based discrimination in criminal proceedings. For these reasons, it would be useful to envisage disability as the basis of discrimination or violation of equality into the substantive elements of relevant criminal offenses, which would largely facilitate the criminal protection of persons with disabilities against discrimination. Such legislation would certainly be in line with international documents in the field of protection against discrimination, as well as with relevant constitutional provisions on the prohibition of discrimination.

The ground legal document which contains anti-discrimination provisions is the European Convention on Human Rights. ${ }^{15}$ Article 14 provides the general prohibition of discrimination. Namely, the enjoyment of the rights and freedoms set forth in this Convention shall be secured without discrimination on any grounds, such as sex, race, colour, language, religion, political or other opinion, national or social origin, association with a national minority, property, birth or other status.

The international document of significantimportance on this matter is the UN Convention on the Rights of Persons with Disabilities, adopted in 2006 and ratified by the Republic of Serbia in $2009 .{ }^{16}$ This Convention is the first binding legal document that explicitly prohibits discrimination against persons with disabilities. The basic objectives of the Convention are: to promote, protect and ensure the full and equal enjoyment of all human rights and fundamental freedoms for all persons with disabilities and to promote respect for their innate dignity. The application of the principles and provisions of the Convention will encourage States parties to

\footnotetext{
${ }^{15}$ The European Convention on Human Rights, https://www.echr.coe.int/Documents/ Convention_ENG.pdf, Accessed on 31October 2019.

${ }^{16}$ Zakon o potvrđivanju Konvencije o pravima osoba sa invaliditetom (Act on Ratification of the Convention on the Protection of the Rights of People with Disabilities, „Službeni glasnik RS-Međunarodni ugovori“, br. 42/2009.
} 
the Convention to actively work on the removal of both architectural and social barriers that prevent persons with disabilities from becoming active factors in the society in which they live and work (Tatić, 2006, p.10). The Republic of Serbia has introduceddisability-based discrimination into its criminal legislationand adopted a lex specialis, Act on the Prevention of Discrimination against Persons with Disabilities of 2006, which is in accordance with the adopted international legal documents.

Another problem that is noticed when protecting persons with disabilities against discrimination is a very small number of initiated and legally terminated criminal proceedings related to the criminal acts involving violation of equality in which people with disabilities appear as injured parties. Bearing in mind the overall social status of people with disabilities in Serbia today, it seems that the assumption is that the dark figures are extremely high in case of discrimination of persons with disabilities. In order to provide empirical verification for this statement, further research on an appropriate sample of respondents is needed, which is likely to be pursued in the future.

In the process of seeking an adequate response to this social phenomenon, it is crucial that citizens are fully aware of and informed about its manifestations in order to recognize it. Well-informed citizens are the best defense against all socially dangerous and harmful phenomena. The awareness of persons with disabilities is a very important factor in preventing discrimination in all areas. The results of thissmall-scale survey show that as many as $70.59 \%$ of respondents do not have enough information on criminal protection against discrimination. In addition, a large percentage of under-informed respondents impose the need to create active policies to raise awareness of this category of people about the mechanisms of legal protection of persons with disabilities against discrimination. These findings indicate that additional measures and actions are needed to further inform persons with disabilities about the possibilities of criminal justice protection against discrimination.

As compared to the previous period, the legal position of persons with disabilities has been significantly improved by means of legislative activity and activism of numerous associations and organizations forpersons with disabilities.Now, at least, it seems that people with disabilities have become "more visible" and that many state institutions deal with the issue of disability in a comprehensive way. However, in order to safeguard the rights of persons with disabilities, it is necessary to constantly and purposely work on amending legal solutions and to insist on their consistent application. In this process, the reform of criminal legislation is of paramount importance, as it should not be forgotten that the legal system is basically a sum of regulations and that no legal provision should be viewed in isolation. 


\section{REFERENCES}

Jovašević, D. (2006) Leksikon krivičnog prava [Criminal Law Lexicon], Belgrade: Službeni glasnik.

Mirić, F. (2017) Protection of people with disabilities against discrimination in Criminal Law, "Globalization and Law", Collection of papers from the International Scientific Conference, held on 20-21 April 2017, Faculty of Law, University of Niš, Niš, pp. 209-220.

Petrušić, N., Ilić, G., Reljanović, M., Ćirić, J., Matić, M., Beker, K., Nenadić, S. and Trninić, V. (2012) Primena antidiskriminacionog zakonodavstva i krivičnopravna zaštita - studija slučaja, praksa $i$ preporuke [The application of Antidiscrimination legislation and criminal law protection-case study, practice and recommendations], Belgrade: Udruženje javnih tužilaca i zamenika javnih tužilaca Srbije.

Tatić, D. (2006) Uvod u Međunarodnu konvenciju o pravima osoba sa invaliditetom [Introduction to the International Convention on the Rights of People with Disabilities], Beograd: Centar za samostalni život invalida Srbije. Retrieved 29 August 2017 from http://www.spiks.org.rs/pdf/uvod_konvenciju.pdf

OSCE:Hate Crime against People with Disabilities, https://www.osce.org/odihr/hatecrime-against-people-with-disabilities?download=true, accessed on 17 November 2019.

\section{Legislation}

The European Convention on Human Rights, https://www.echr.coe.int/Documents/ Convention_ENG.pdf, accessed on 31October 2019.

Kazenenski zakonik Republike Slovenije, Uradni list Slovenije, 55/2008...27/2017.

Kazneni zakonik Republike Hrvatske Narodne novine, br.125/2011,... 118/2018.

Krivičen zakonik na Republika Makedonija, Služben vesnik na RM, 80/99...132/2014.

Krivični zakon Bosne i Hercegovine, Službeni glasnik Bosne i Hercegovine, 3/2003... $35 / 2018$.

Krivični zakon Brčko Distrikta Bosne i Hercegovine, Službeni glasnik BD BiH, 33/2013...50/2018.

Krivični zakon Federacije Bosne i Hercegovine, Službene novine FBiH“, 36/2003... $75 / 2017$.

Krivični zakonik Crne Gore, Službeni list RCG i Službeni list CG, 70/2003...49/2018.

Krivični zakonik Republike Srbije, Službeni glasnik Republike Srbije, br.85/2005... 94/2016.

Krivični zakonik Republike Srpske, Službeni glasnik Republike Srpske, 64/2017, $104 / 2018$

Ustav Republike Srbije, Službeni glasnik Republike Srbije, br. 98/2006.

Zakon o izmenama i dopunama Krivičnog zakonika Republike Srbije,Službeni glasnik Republike Srbije, br. 96/2016.

Zakon o potvrđivanju Konvencije o pravima osoba sa invaliditetom, Službeni glasnik $R S$-Međunarodni ugovori, br. 42/2009.

Zakon o sprečavanju diskriminacije osoba sa invaliditetom, Službeni glasnik RS, $33 / 2006$. 


\title{
ИНФОРМИСАНОСТ ОСОБА СА ИНВАЛИДИТЕТОМ О КРИВИЧНОПРАВНОЈ ЗАШТИТИ ОД ДИСКРИМИНАЦИЈЕ У ДРЖАВАМА БИВШЕ СФРЈ
}

\author{
Филип Мирић \\ Универзитет у Нишу, Правни факултет, Ниш, Србија
}

\section{Резиме}

Дискриминација особа са инвалидитетом је веома распрострањен друштвени феномен. Последњих година Србија је, усвајањем низа закона из области заштите од дискриминације (Закон о спречавању дискриминације особа са инвалидитетом, Закон о забрани дискриминације, Закон о професионалној рехабилитацији и запошљавању особа са инвалидитетом), успешно заокружила свој нормативни оквир. Када је реч о заштити од дискриминације, обично се мисли на грађанскоправну заштиту и на накнаду материјалне и нематеријалне штете. Осим грађанскоправне заштите, правни поредак Републике Србије прописује и кривичноправну заштиту од дискриминације. Циљ рада је да се, коришћењем посебно дизајнираног упитника, истражи колико су саме особе са инвалидитетом упознате са механизмима кривичноправне заштите од дискриминације. Информисаност о правима и начину њихове заштите је предуслов успешне примене законских решења. Резултати спроведеног истраживања показали су да особе са инвалидитетом у Србији нису у довољној мери информисане о начинима кривичноправне дискриминације. У овоме треба тражити и узрок веома малог броја окончаних кривичних поступака из ове области у Србији, што је један од разлога неповољног друштвеног и правног положаја ове групе људи.

У процесу тражења адекватног одговора на овај друштвени феномен, од пресудног је значаја информисаност грађана, у циљу њеног препознавања. Добро информисани грађани су најбоља одбрана од свих друштвено опасних и штетних појава. Информисаност особа са инвалидитетом је веома важан фактор превенције дискриминације у свим областима. Резултати спроведеног истраживања показују да чак 70,59 посто испитаника нема довољно информација о кривичноправној заштити од дискриминације. Осим тога, велики проценат недовољно информисаних испитаника на ову тему намеће потребу осмишљавања активних политика подизања свести ове категорије људи о механизмима правне заштите особа са инвалидитетом од дискриминације. Ови налази показују да је неопходно осмишљавање додатних мера и акција, како би се особе са инвалидитетом у будућности додатно информисале о могућностима кривичноправне заштите од дискриминације. 